\title{
Detection of lyssavirus antigen and antibody levels among apparently healthy and suspected rabid dogs in South-Eastern Nigeria
}

\author{
Ukamaka U. Eze ${ }^{1^{*}} \mathbb{1}$, Ernest. C. Ngoepe ${ }^{2}$, Boniface M. Anene ${ }^{1}$, Romanus C. Ezeokonkwo ${ }^{3}$, Chika Nwosuh ${ }^{4}$ \\ and Claude T. Sabeta ${ }^{2,5}$
}

\begin{abstract}
Objectives: Domestic dogs are the main reservoir of rabies virus (RABV) infection in Nigeria, thus surveillance of rabies in dog populations is crucial in order to understand the patterns of spread of infection and ultimately devise an appropriate rabies control strategy. This study determined the presence of lyssavirus antigen in brain tissues and anti-rabies antibodies in sera of apparently healthy and suspected-rabid dogs slaughtered for human consumption at local markets in South-Eastern Nigeria.

Results: Our findings demonstrated that $8.3 \%(n=23)$ of brain tissues were lyssavirus positive and $2.5 \%(n=25)$ of sera had rabies antibody levels as percentage blocking of $70 \%$ and above correlating with a cut-off value $\geq 0.5$ IU/ $\mathrm{mL}$ in the fluorescent antibody neutralization test. There was an inverse correlation between lyssavirus positivity and rabies antibody levels confirming that infected individuals most often do not develop virus neutralizing antibodies to the disease. The low percentage of rabies antibodies in this dog population suggests a susceptible population at high risk to RABV infection. These findings highlight a huge challenge to national rabies programs and subsequent elimination of the disease from Nigeria, considering that majority of dogs are confined to rural communal areas, where parenteral dog vaccination is not routinely undertaken.
\end{abstract}

Keywords: Lyssavirus, Dogs, Antigen, Antibodies, DFA, ELISA

\section{Introduction}

The aetiologic agent of rabies is rabies virus (RABV); a non-segmented single-stranded RNA virus and member of the genus Lyssavirus (family Rhabdoviridae, order Mononegavirales). In Africa and Asia, approximately 99\% of human rabies cases are dog-mediated [1], making rabies a disease of significant public and veterinary health threat, albeit that it is preventable through parenteral vaccination. Consumption of dog meat is common in some specific regions of Nigeria. This practice is a potential risk for the importation of RABV-infected dogs

\footnotetext{
*Correspondence: Ukamakauchenna.eze@unn.edu.ng

1 Department of Veterinary Medicine, Faculty of Veterinary Medicine,

University of Nigeria, Nsukka, Enugu State, Nigeria

Full list of author information is available at the end of the article
}

into the dog markets for slaughter from different regions and countries. Consequently, handling and processing of such meat exposes meat-handlers to potentially RABVinfected dogs [2-4]. Previous studies demonstrated that some of the slaughtered dogs were infected with lyssaviruses [2-4]. Despite these observations, neither surveillance nor a tangible rabies control strategy has been formulated and deployed by local governments.

For routine diagnosis of RABV, detection of viral antigen in the central nervous system tissues is generally undertaken by the use of the direct fluorescent antibody test (DFA) [5], applying either a fluorescein isothiocyanate (FITC) labelled anti-rabies monoclonal (Mab) or Polyclonal antibody (Pab) to an acetone-fixed composite brain smear [6]. Virus neutralizing antibodies (NAs) are a 
key component of the adaptive immune response against viral pathogens including RABV [7], and neutralization assays are currently the gold standard test for assessing NAs. The Fluorescent antibody virus neutralization test (FAVNT) [8] and the rapid fluorescent foci inhibition test (RFFIT) [9] are both recommended by the World Health Organization (WHO) and the World Organization for Animal Health (OIE) $[6,10]$. In addition, ELISA assays can be considered as alternatives to neutralization assays, especially for use in epidemiological surveys where large numbers of samples are involved and in laboratories where cell culture facilities with appropriate containment for neutralization assays may be lacking $[6,11]$. In Nigeria, previous studies in dog populations have involved serological analysis [12-15]. However, there is dearth of information on the antigenic status of dogs whose sera were examined. This study was therefore undertaken to assess the presence of lyssavirus antigen in parallel to levels of anti-glycoprotein antibodies among apparently healthy and rabies-suspect dogs slaughtered for meat consumption in local markets in South-Eastern Nigeria.

\section{Main text \\ Methodology \\ Study area}

A total of 278 brain tissues and accompanying serum samples were collected from both apparently healthy and rabies-suspect dogs at (dog) markets, restaurants and veterinary clinics in three South-Eastern States of Nigeria (Enugu, Ebonyi and Anambra) (latitudes $7^{\circ} 07^{\prime} \mathrm{N}$ and $3^{\circ} 90^{\prime} \mathrm{N}$ and longitudes $6^{\circ} 51^{\prime} \mathrm{E}$ and $8^{\circ} 30^{\prime} \mathrm{E}$ ) (see map of study area, Additional file 1) between October 2015 and July 2016.

\section{Specimen collection}

The criteria used in this study, to identify rabies-suspect dogs were based on history and typical clinical presentation [16-18]. Dogs without history of rabies and not displaying clinical signs of the disease prior to slaughter were considered apparently healthy. For each dog, brain sample was collected and stored in a leak-proof container. Also $3 \mathrm{~mL}$ of blood was collected from the cephalic vein into a vacutainer, allowed to clot, and then centrifuged at $3000 \mathrm{rpm}$ for $15 \mathrm{~min}$ (Centromix, P. Selecta; Barcelona), to separate the serum. All samples were stored at $-20^{\circ} \mathrm{C}$ until tested.

\section{Rabies virus antigen detection}

Brain tissues were subjected to the DFA test [5] with a lyophilized, adsorbent anti-rabies nucleocapsid monoclonal globulin labeled with FITC (Fujirebio ${ }^{\circledR}$, USA) at the National Veterinary Research Institute (NVRI, Jos, Nigeria), according to the manufacturer's guidelines.
Brain samples were retested using anti-rabies nucleocapsid monoclonal globulin labeled with FITC $\left(\right.$ BIORAD $\left.^{\circledR}\right)$ at the Rabies Unit, Onderstepoort, South Africa, (an OIE Rabies Reference Laboratory). The presence of lyssavirus antigen was confirmed by observation of typical clusters of apple green fluorescing aggregates of Negri bodies under UV fluorescence.

\section{Rabies virus neutralizing antibody detection}

Assessment of antibody levels was conducted at the Rabies Unit, Onderstepoort, South Africa on heat-inactivated sera (at $56{ }^{\circ} \mathrm{C}$ for $30 \mathrm{~min}$ ) [8]. The BioPro ELISA kit (BioPro, Prague, Czech Republic) based on a blocking ELISA protocol was used to detect the presence or absence of anti-glycoprotein rabies antibodies. To confirm the results from The ELISA test, the FAVNT was done on selected samples and their end-point titres established. The BioPro ELISA kit has been validated by several global OIE Rabies Reference Laboratories to support as a potential alternative to seroneutralization assays for monitoring oral vaccination [11]. The percentage blocking $(\mathrm{PB} \%)$ of each serum sample was calculated in the serum samples, according to the manufacturer's recommendations and interpreted as per OIE and WHO recommendations $[19,20]$. Serum samples with $\mathrm{PB}<40 \%$ are considered negative, while serum samples with $\mathrm{PB}$ $\geq 40 \%$ but $<70 \%$ are considered positive for RABV antibodies when antibody levels are $\leq 0.5 \mathrm{IU} / \mathrm{mL}$ on $\mathrm{VN}$ test. Serum samples with $\mathrm{PB} \geq 70 \%$ are considered positive when antibody levels are $\geq 0.5 \mathrm{IU} / \mathrm{mL}$ on the FAVNT $[19,20]$. In addition, the FAVNT was performed on all serum samples with $\mathrm{PB} \geq 40 \%$ to establish their endpoint titres [8]. The three microplates used in the ELISA assay showed that the optical density (OD) of the positive and negative controls of all the microplates met the validation criteria indicated by the manufacturer.

\section{Statistical analyses}

Serological results were summarized using descriptive statistics on the GraphPad prism statistical package version 5.2 for Windows (GraphPad Software, La Jolla California USA, http://www.graphpad.com). Chi square test was used to test association between the presence of lyssavirus antigen and health status and presence of lyssavirus antigen versus location. Odds ratio was used to determine the strength of association between the variables. Correlation and regression analysis were done to test relationship between ELISA and FAVNT.

\section{Results}

The prevalence of lyssaviruses in the study population was $8.3 \%(n=23)$. Three $(4.8 \%)$ of the 62 samples collected from Anambra State were lyssavirus positive, 
compared to two (3.1\%) out of 65 samples collected from Ebonyi State, whereas 18 (11.9\%) out of 151 samples collected from Enugu State tested positive for rabies virus antigen. There was no association $(P>0.05)$ between distribution of lyssavirus antigen and state of origin of the dogs sampled. However, there was a strong association $(\mathrm{P}>0.05)$ between the presence of lyssavirus antigen and health status of dogs as dogs suspected to be rabid showed significantly higher number of lyssavirus positive brain tissues than the apparently healthy dogs, Fig. 1.

Of the 260 serum samples collected, only 252 serum samples were included in the final analysis as eight of the samples were lipaemic and thus not suitable for testing. The PB distribution of the ELISA results showed that 233 (92\%), $14(5.6 \%)$ and $5(2.0 \%)$ lie in the ranges between -1 to $39 \%, 40$ to $69 \%$ and $\geq 70 \%$, respectively Table 1 .

There was no correlation between the PB of the serum and the presence of lyssavirus antigen as the brain tissues

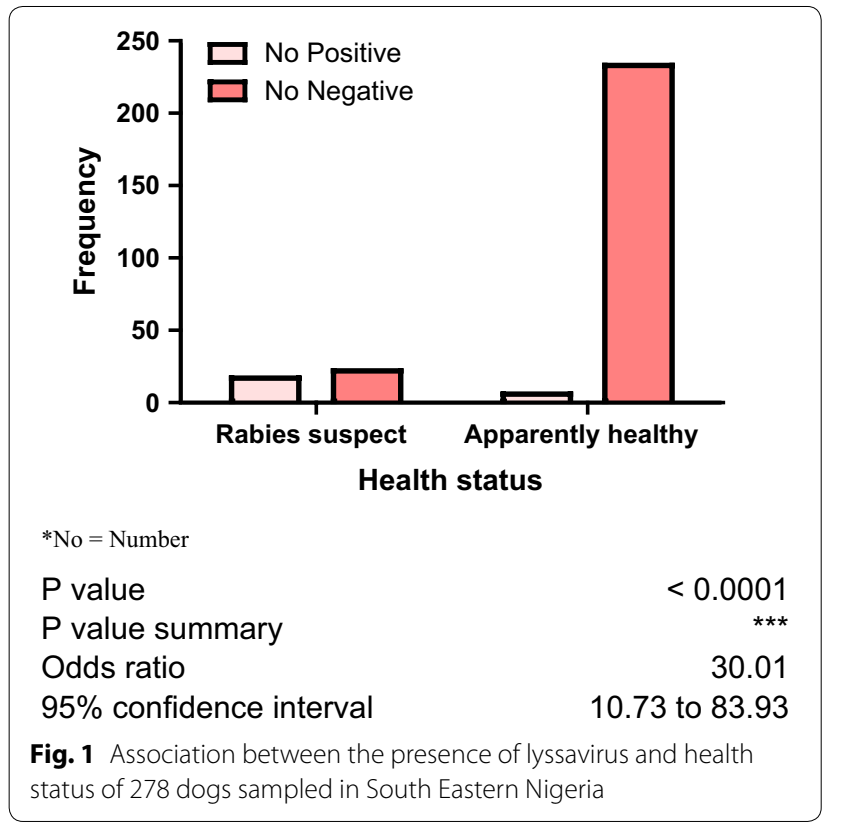

that had $\mathrm{PB}$ of $\geq 70 \%$ were all DFA negative. However, there was a strong correlation between the blocking ELISA and the FAVNT results, Fig. 2.

All the samples that have $\mathrm{PB}$ of $\geq 70 \%$ were above $0.5 \mathrm{IU} / \mathrm{mL}$ (with FAVNT), a cut-off value indicating adequate seroconversion of a dog following vaccination or a possible exposure to a lyssavirus within phylogroup1 [21, 22].

\section{Discussion}

This study was designed to determine the presence of lyssavirus antigen and quantify rabies anti-glycoprotein antibody in a cross-section of dogs at point of slaughter in local markets in South-Eastern Nigeria. The findings established presence of lyssavirus antigen in both apparently healthy and rabies-suspect dogs in South-Eastern Nigeria in approximately $8.3 \%$ of the dogs tested $(n=23)$. However, $2.5 \%(n=6)$ were from dogs that were apparently healthy at the time of slaughter. These findings corroborated earlier reports that detected lyssavirus antigen in the brains of apparently healthy dogs slaughtered at local markets in Nigeria sometimes originating from different regions of the country. Earlier reports indicated prevalence of between 1.58 and 5\% [2, 3, 23, 24]. Two independent groups isolated RABV from apparently healthy dogs following several passages in cell culture [25] and in mice and demonstrated these isolates are different from vaccinal strains [26].

The high numbers of suspect-rabid dogs [17 (43.6\%)] probably reflects that the true burden of rabies in Nigeria is grossly underestimated, but also strengthens the argument for the need to enhance the knowledge of the public health hazards of rabies amongst dog marketers in South-Eastern Nigeria. Generally speaking, positive dog rabies cases confirmed from the (dog) markets are not included in the annual rabies data reported to the OIE. As a result, rabies is highly underreported, with likelihood that rabies is at least hundred fold higher than officially reported. Furthermore, national governments do

Table 1 Summary of the ELISA results from the three States in South Eastern Nigeria where dog sera samples were collected for Lyssavirus antibodies assessment

\begin{tabular}{|c|c|c|c|c|c|}
\hline States & Percentage blocking & $\begin{array}{l}\text { Anambra } \\
N(\text { Pos \%) }\end{array}$ & $\begin{array}{l}\text { Ebonyi } \\
\text { N (Pos \%) }\end{array}$ & $\begin{array}{l}\text { Enugu } \\
\mathrm{N}(\text { Pos \%) }\end{array}$ & $\begin{array}{l}\text { Total } \\
\text { N (Pos \%) }\end{array}$ \\
\hline \multicolumn{6}{|c|}{ Locality of origin of samples } \\
\hline \multirow{3}{*}{$\begin{array}{l}\text { Ranges of Percentage } \\
\text { blocking }\end{array}$} & -1 to 39 & $56(93.3)$ & $59(95.2)$ & $118(90.8)$ & $233(92.5)$ \\
\hline & 40 to 69 & $4(6.7)$ & $1(1.6)$ & $9(6.9)$ & $14(5.6)$ \\
\hline & 70 and above & $0(0)$ & $2(3.2)$ & $3(1.5)$ & $5(2.0)$ \\
\hline $\begin{array}{l}\text { Total number collected } \\
\text { from each state }\end{array}$ & & 60 & 62 & 130 & 252 \\
\hline
\end{tabular}

$N($ pos $\%)=$ number positive 


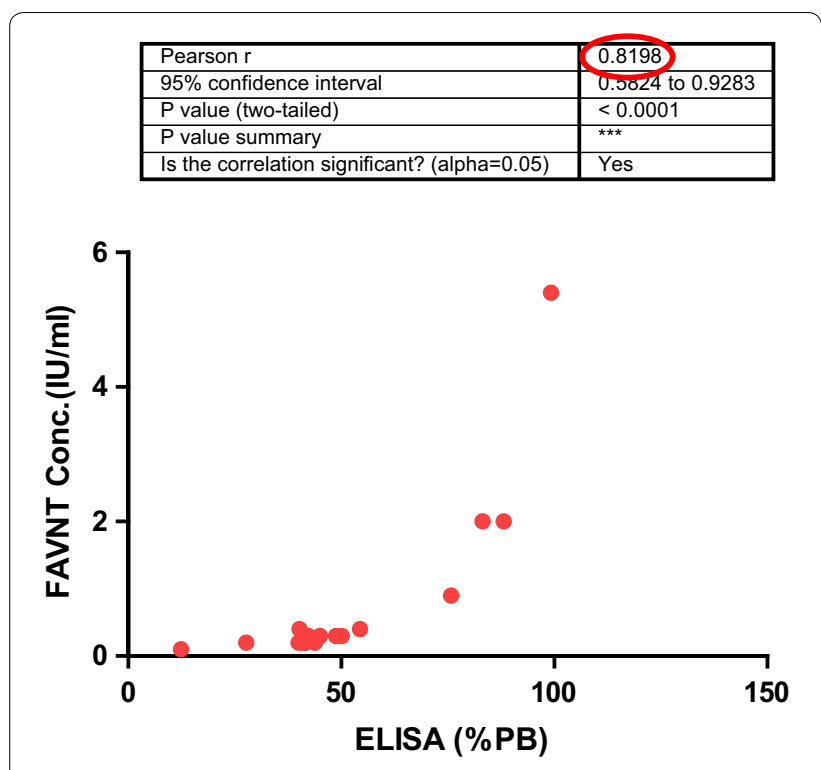

Fig. 2 Correlation between ELISA and FAVNT

not seem to prioritize rabies but findings from this study may inform policy change, to ensure that rabies is placed high on the priority list.

Dog markets present areas with a potential risk of rabies outbreaks and transmission to humans. This makes dog markets particularly significant and strategic because the people selling dogs in Nigeria bring dogs from different parts of the country, including illegal importations $[27,28]$.

The ELISA results demonstrated that majority of the dogs slaughtered for consumption lack detectable levels of rabies antibodies in their sera, an indication of the high susceptibility of this dog population to RABV infection. Only $2 \%$ of the dogs' population possessed antibodies against rabies indicating very low herd immunity. This finding further suggest that little or no dog vaccination takes place in the rural areas and is consistent with observations from other parts of the country [12, 13]. RABV-specific antibodies detected in some apparently healthy wild terrestrial carnivores and bats probably suggest exposure of these animals to lyssaviruses including RABV [29-32].

The results of FAVNT on the small panel of serum samples corroborated the results of the blocking ELISA, which is consistent with findings from Wasniewski et al. [11] who concluded that the ELISA is reliable and reproducible, and could be useful in rabies antibody detection especially during sero-surveys. This is particularly important for a Nigerian setting where containment laboratory for FAVNT is lacking. Rabies-infected dogs had no detectable rabies antibodies confirming observations that infected individuals most often do not develop VNAs [33]. Failure of the host (dog) to produce a protective response that successfully resolves the infection or reduces the severity of the disease could be explained by the immune evasion triggered by pathogenic lyssaviruses [34]. Only two of the dogs infected with RABVs had PB\% of $54 \%[0.4 \mathrm{IU} / \mathrm{mL}]$ and $48 \%[0.3 \mathrm{IU} / \mathrm{mL}]$ respectively, which were well above the first cut off value (of $40 \%$ ), which suggests that these dogs may be in the advanced stage of the disease at the time of slaughter. Appropriate studies on the pathogenicity, cell mediated immunity and humoral responses in a natural canine host (dog) may help to shed more light on the mechanisms of immune responses to infection in this species.

\section{Conclusion}

In conclusion, this study has demonstrated that there is some likelihood of some dogs destined for the markets to be rabies-infected and a large number of rabies naive dogs exist in rural South-Eastern Nigeria. In addition, the importation of unvaccinated dogs, slaughter and processing of dog meat in these markets contributes to the cycle of neglect resulting in rabies being under-reported in Nigeria. Consequently, this may make elimination of dogmediated human rabies deaths difficult to achieve by the set target of 2030. Therefore, mass dog vaccination campaigns in rural regions of Nigeria should be enhanced in order to successfully eliminate dog rabies.

\section{Limitation}

Although in this study, we used the DFA which is the gold standard test for rabies diagnosis recommended by WHO, however other confirmatory tests such as mouse inoculation test and reverse-transcriptase polymerase chain reaction were not used to confirm negative results.

\section{Additional file}

Additional file 1. Geographical location of South Eastern Nigeria and the States involved in the study. Map of the study area.

\section{Abbreviations}

ELISA: enzyme-linked immunosorbent assay; FAVNT: fluorescent antibody virus neutralization test; RABV: rabies virus; DFA: direct fluorescent antibody test; RNA: ribonucleic acid; FITC: fluorescein-isothiocyanate; Mab: monoclonal antibody; Pab: polyclonal antibody; NAs: neutralizing antibodies; RFFIT: rapid fluorescent foci inhibition test; WHO: World Health Organization; OIE: World Organization for Animal Health; NVRI: National Veterinary Research Institute; UV: ultra violet; PB: percentage blocking; OD: optical density; VN: virus neutralization.

\section{Authors' contributions}

UUE and CTS designed the study. UUE, BMA, RCE and CN collected the sample and data. ECN, UUE and CTS did the serology. CTS and UUE performed the statistical analysis and wrote the paper. BMA, RCE, CN and CTS reviewed 
and coordinated the manuscript. All authors read and approved the final manuscript.

\section{Author details}

${ }^{1}$ Department of Veterinary Medicine, Faculty of Veterinary Medicine, University of Nigeria, Nsukka, Enugu State, Nigeria. ${ }^{2}$ OIE Rabies Reference Laboratory, Agricultural Research Council-Onderstepoort Veterinary Institute, Onderstepoort, South Africa. ${ }^{3}$ Department of Veterinary Parasitology and Entomology, Faculty of Veterinary Medicine, University of Nigeria, Nsukka, Enugu State, Nigeria. ${ }^{4}$ National Veterinary Research Institute, Vom, Plateau State, Nigeria. ${ }^{5}$ Department of Veterinary Tropical Diseases, University of Pretoria, Onderstepoort 0110, South Africa.

\section{Acknowledgements}

The authors thank staff of National Veterinary Research Institute, Vom Plateau State, Nigeria and OIE Rabies Reference Laboratory, Onderstepoort, South Africa for laboratory and technical support. We also thank Dr. Ekene Ezenduka for assistance with the data analysis.

\section{Competing interests}

The authors declare that they have no competing interests.

\section{Availability of data and materials}

All data generated or analyzed during this study and supporting the conclusions of this article are included within the article.

\section{Consent for publication}

Not applicable.

\section{Ethics approval and consent to participate}

The authors assert that all procedures contributing to this work comply with the ethical standards of the relevant national and institutional guides on the care and use of animals. Approved by University of Nigeria ethical committee; approval number- UNN/eTC/14/68625

\section{Funding}

This work was partly funded by the Tertiary Educational Trust Fund (TETFund) of the Nigerian government through University of Nigeria IBR Intervention (TETFUND/DESS/UNI/NSUKKA/RP/NOL.V) and the ARC-OVI National Assets [P10000029]. The bench work was undertaken at the Rabies Unit, Onderstepoort Veterinary Institute, South Africa. The TETFund and ARC-OVI National Assets were involved in the design of the study, TETFund funded the collection of data and analyses in Nigeria, while the ARC-OVI was responsible for the analyses of data in South Africa and manuscript writing.

\section{Publisher's Note}

Springer Nature remains neutral with regard to jurisdictional claims in published maps and institutional affiliations.

\section{Received: 27 November 2018 Accepted: 17 December 2018} Published online: 22 December 2018

\section{References}

1. Hampson K, Coudeville L, Lembo T, Sambo M, Kieffer A, Attlan M, Costa P. Estimating the global burden of endemic canine rabies. PLoS Negl Trop Dis. 2015;9:e0003709.

2. Otolorin GR, Umoh JU, Dzikwi AA. Prevalence of rabies antigen in brain tissue of dogs slaughtered for human consumption and evaluation of vaccination of dogs against rabies in Aba, Abia State Nigeria. World J Public Health Sci. 2014;3(1):5.

3. Eze UU, Anene BM, Chukwu CC, Ogunkoya AB, George SO, Eze Jl, Animoke PC, Nwosuh Cl. Risk of typical rabies in dog meat-eating human population, in Enugu, Nigeria. Int J Public Health Epidemiol. 2015:4(1):107-9.

4. Konzing L, Umoh JU, Dzikwi AA. Trade dog-dog meat processors interface in rabies transmission. Int J Appl Res. 2015;1(11):83-91.
5. Dean DJ, Abelseth MK, Atanasiu P. The fluorescent antibody test. In: Meslin F-X, Kaplan MM, Koprowski H, editors. Laboratory techniques in rabies, 4th edn. Geneva: World Health Organization; 1996. p. 88-95.

6. Office Internationale des epizootics (OIE). Rabies (infection with rabies virus) and other lyssaviruses. OIE terrestrial Manual. 2018; 2.1.17.

7. Moore SM, Pralle S, Engelman L, Hartschuh H, Smith M. Rabies vaccine response measurement is assay dependent. Biologicals. 2016;44:481-6. https://doi.org/10.1016/j.biologicals.2016.09.007.

8. Cliquet F, Aubert M, Sagne L. Development of a fluorescent antibody virus neutralisation test (FAVN test) for the quantitation of rabiesneutralising antibody. J Immunol Methods. 1998;212:79-87. https://doi. org/10.1016/S0022-1759(97)00212-3.

9. Smith JS, Yager PA, Baer GM. A rapid reproducible test for determining rabies neutralizing antibody. Bull World Health Org. 1973;48:535-41.

10. World Health Organization. WHO expert consultation on rabies: third report. 2018. http://apps.who.int/iris/bitstream/handle/10665/27236 4/9789241210218-eng.pdf. Accessed 6 June 2018.

11. Wasniewski M, Almeida I, Baur A, Bedekovic T, Boncea D, Chaves LB, David D, De Benedictis P, Dobrostana M, Giraud P, Hostnik P, Jaceviciene I, Kenklies S, König M, Mähar K, Mojzis M, Moore S, Mrenoski S, Müller T, Ngoepe E, Nishimura M, Nokireki T, Pejovic N, Smreczak M, Strandbygaard B, Wodak E, Cliquet F. First international collaborative study to evaluate rabies antibody detection method for use in monitoring the effectiveness of oral vaccination programmes in fox and raccoon dog in Europe. J Virol Methods. 2016;238:77-85. https://doi.org/10.1016/j.jviro met.2016.10.006.

12. Wosu LO, Anyanwu HN. Seroepidemiological survey of rabies virus antibodies in nonvaccinated dogs in Nsukka Environs, Nigeria. J Commun Dis. 1990:22:124-8.

13. Olugasa BO, Aiyedun JO, Emikpe BO. Prevalence of antibody against rabies among confined, free-roaming and stray dogs in a transit city of Nigeria. Veterinarialtaliana. 2011; 47:453-60. https://www.ncbi.nlm.nih. gov/pubmed/22194227.

14. Adeyemi I, Zessin K. Retrospective dog rabies vaccination evaluation at the University of Ibadan, Nigeria (1988-1992). Veterinarski ARHIV. 2000; 70:223-30. Please rephrase. I will say greater than or equal to $40 \%$ but less than $70 \%$. (Google Scholar).

15. Ohore OG, Emikpe BO, Oke OO, Oluwayelu DO. The seroprofile of rabies antibodies in companion urban dogs in Ibadan, Nigeria. J Anim Vet Adv. 2007:6(1):53-6.

16. Office International des Epizootics (OIE). National Rabies Surveillance. Follow up workshop on relevant international standards for dog rabies Bangkok, Thailand; 2016.

17. Haig DA. Rabies in animals. In: Kaplan C, editor. Rabies: the facts. London: Oxford University Press; 1976.

18. CDC. Protocol for postmortem diagnosis of rabies in animals by direct fluorescent antibody testing, a minimum standard for rabies diagnosis in the United States. 2008. http://www.cdc.gov/ncidod/dvrd/rabies/Profe ssional/publications/DFA_diagnosis/DFA_protocol-b.htm.

19. World Health Organization. Technical report series 931. WHO expert consultation on rabies. Geneva, Switzerland; 2005. p. 1-87. (Google Scholar)

20. Office Internationale des epizootics (OIE). Manual of diagnostic tests and vaccines for terrestrial animals (mammals, birds and bees). 7th ed. Paris: OIE; 2012.

21. World Health Organization. WHO expert consultation rabies. TRS 982 ed. Geneva: World Health Organization; 2012.

22. Fooks A, Horton D, Muller T, Frueling C, Ruppretch C. Manual of diagnostic tests and vaccines for terrestrial animals (mammals, birds and bees). 7th ed. Paris: Office International Des Epizooties; 2012. p. 263-82.

23. Ajayi BB, Rabo JS, Baba SS. Rabies in apparently healthy dogs histochemical and immunohistochemical studies. Nigerian Postgrad Med J. 2006:13:128-34.

24. Aliyu TB, De N, Yenda EN, Lynn M. Prevalence of rabies virus antigen in apparently healthy dogs in Yola, Nigeria. Sci Res Publish. 2010;2(2):1-14

25. Tekki IS, Meseko CA, Omotainse SO, Atuman YJ, Chukwukere, Olaleye S, Okewole PA. Incidences of rabies in domestic animals and consequent risk factors in humans. J Med Microbiol Diagn. 2014;3:143. https://doi. org/10.4172/2161-0703.1000143.

26. Aghomo HO, Rupprecht CE. Further studies on rabies virus isolated from healthy dogs in Nigeria. Vet Microbiol. 1990;22:17-22. https://doi. org/10.1016/0378-1135(90)90120-K. 
27. Ogunkoya AB. Review of rabies and problems of rabies in Nigeria. In: Proceedings of the National conference/work on rabies, Ahmadu Bello University, Zaria, Nigeria; 2008. p. 62-70.

28. Garba A, Dzikwi AA, Okewole PA, Chitunya-Wilson BB, Tirmidh AB, Kazeem HM, Umoh JU. Evaluation of dog slaughter and consumption practices related to the control of rabies in Nigeria. J Exp Biol Agric Sci. 2013;1(2):126-30.

29. Aghomo HO, Ako-Nai AK, Oduye OO, Tomori O, et al. Detection of rabies virus antibodies in fruit bats (Eidolon helvum) from Nigeria. J Wildl Dis. 1990;26:258-61. https://doi.org/10.7589/0090-3558-26.2.258.

30. East ML, Hofer $\mathrm{H}, \mathrm{Cox} J \mathrm{H}$, Wulle U, et al. Regular exposure to rabies virus and lack of symptomatic disease in Serengeti spotted hyenas. Proc Nat Acad Sci USA. 2001;98:15026-31. https://doi.org/10.1073/pnas.26141 1898.
31. Gilbert AT, Petersen BW, Recuenco S, Niezgoda M, Gómez J, LagunaTorres VA, Rupprecht C. Evidence of rabies virus exposure among humans in the peruvian amazon. Anim J Trop Med Hyg. 2012;1(87):206-15. https ://doi.org/10.4269/ajtmh.2012.11-0689.

32. Tyem DA, Dogonyaro BB, Woma TA, Ngoepe EC, Sabeta CT. Sero-surveillance of lyssavirus specific antibodies in Nigerian fruit bats (Eidolon helvum). Trop Med Infect Dis. 2017;2:26. https://doi.org/10.3390/tropi calmed2030026.

33. Hemachudha T. Human rabies: clinical aspects, pathogenesis, and potential therapy. Curr Top Microbiol Immunol. 1994;187:121-43.

34. Ito N, Moseley GW, Sugiyama M. The importance of immune evasion in the pathogenesis of rabies virus. J Vet Med Sci. 2016;78(7):1089-98. https ://doi.org/10.1292/jvms.16-0092.
Ready to submit your research? Choose BMC and benefit from:

- fast, convenient online submission

- thorough peer review by experienced researchers in your field

- rapid publication on acceptance

- support for research data, including large and complex data types

- gold Open Access which fosters wider collaboration and increased citations

- maximum visibility for your research: over $100 \mathrm{M}$ website views per year

At BMC, research is always in progress.

Learn more biomedcentral.com/submissions 